\title{
EDITORIAL
}

\section{COMISSAO DE ESPECIALISTAS DO ENSINO DE ENFERMAGEM}

A 17 de abril do corrente ano, por Portaria do Ensino Superior do Ministério da Educação e Cultura, foi instruída mediante a designação de seus membros - a Comissão de Especialistas do Ensino de Enfermagem. A Comissão do Ensino Médico, do Ensino de Odontologia e outras. cada qual em sua área, assessoram a Secretaria de Ensino Superior, com o objetivo de melhorar a qualidade da educação universitária de seu cámpo.

Não somente a Secretaria do Ensino Superior, mas também o Conselho Federal de Educação vale-se da contribuição das Comissões de Especialistas do Ensino.

Por que existem tais Comissões? Os Ministérios, que integram o Poder Executivo da União, têm que realizar as trabalhos próprios de suas atribuições. No caso que astamos considerando, o Setor Educação tem de desincumbir-se cie sua parte. Constitui os órgãos, faz a lotação e a designação do pessnal necessário. $O$ grande volume de trabalho está sendo executado.

Em outra área estão as Universidades, de direito público ou privado; e ostão a serviço de assistência, por exemplo, com ligaçōes docentes-assistenciais; o ensino de $3 .^{\circ}$ grau, indissociável da pesquisa, é uma área que tem especialistas. $O$ Ministério da Educação e Cultura quer ouvir um grupo de pessoas altamente conceituadas em suas áreas profissionais a fim de se valer de seus conhecimentos. Deseja o MEC sua contribuição específica para o Governo utilizá-la no traçado de diretrizes e em açōes que propugnem o ensino racional. E importante serem pessoas ativas em seus próprios campos profissionais, - professores e especialistas com maturidade para discernir medidas e prever seus efeitos no País. $O$ fato de trabalharem como especialistas para - MEC, devotando a estas atribuições semanas por ano, e voltando ao trabalho habitual em seu campo é que assegura condições para permanecerem atualizados.

Para a Associação Brasileira de Enfermagem, a indicação da Comissão referida é motivo de grande júbilo. Terão, desse modo, as entidades de ensino 
de 3. grau de enfermagem, impulsionadas pela SESu, condições de prosseguir bem, corigindo-se no que for indicado, suprindo-se daqueles recursos que thes forem dados e, finalmente, estimulando-se a agir com criatividade para a formação de profissionais competentes.

Para que o leitor acompanhe com interesse a presente notícia, nós o remetemos ao conhecimento de modalidades anteriores dessas comissōes, em que enfermeiras têm contribuído. Em 1962 o Diretor da então Diretoria do Ensino Superior designou a Comissão de Peritos em Enfermagem, de cinco membros, sob a presidência da Prof. ${ }^{a}$ Maria Rosa S. Pinheiro. Esta Comissão clabcrou um proposta de currículo atualizado para a formação de enfermeiros, contendo, pela primeira vez, créditos em sua carga horária.

Em 1965 e 1966, outras duas comissões, a primeira com atribuições explícitas e a segunda designada Comissão de Especialistas do Ensino de Enfermagem (CEE Enfermagem) instituídas pelas Portarias n. ${ }^{\circ}$ 136/65 e 132/66 cla DESu, fizeram os trabalhos que lhes foram solicitados. A Comissão de 1966 esteve sob a coordenação da Prof. ${ }^{a}$ Waleska Paixão. $U m$ dos documentos finais destas duas comissões - ambas eram constituídas das mesmas pessoas está publicado no livro da Prof. ${ }^{a}$ Anayde Corrêa de Carvalho, intitulado Associação Brasileira de Enfermagem - Documentário, 1976. pág. 485-495. Em 1975, valeu-se o mesmo órgão do $M E C$, o então Departamento de Assuntos Universitários (DAU) de um grupo de três especialistas, - Prof. ${ }^{a_{s}}$ Maria Rosa S. Pinheiro, Maria Dolores Lins de Andrade e Maria Nilda de Andrade. Desta comissão recebeu, em março do mesmo ano de 1975, o Diagnóstico do Ensinc de Enfermagem. Outros trabalhos têm sido confiados a estas citadas e a outras especialistas, - Prof. ${ }^{a_{s}}$ Lygia Paim, Luiza Aparecida Teixeira da Costa, Iêda Rareira e Castro, Dilce Rizzo Jorge e Amália Corrêa de Carvalho, de 1975 até fins de 1978.

Há grande significação de se ter a recém-criada Comissão de Especialistas to Ensino de Enfermagem.

No País, hoje, as Comisões de Especialistas de Ensino têm sua inserção nos outros componentes da cultura. Desse modo, a atual Comissão é mais importante do que os grupos similares aqui descritos. Esta de agora vai completar o complexo institucional da enfermagem. Quanto ao trabalho interno que deve desenvolver, continuará, por certo, tradição de competência, cidadania e cultura profissional que tem ilustrado sua classe e beneficiado seu País. (H.G.D.) 